\title{
In vitro atovaquone/proguanil susceptibility and characterization of the cytochrome $b$ gene of Plasmodium falciparum from different endemic regions of Thailand
} Rommanee Khositnithikul${ }^{1}$, Peerapan Tan-ariya ${ }^{1}$ and Mathirut Mungthin*2

\author{
Address: ${ }^{1}$ Department of Microbiology, Faculty of Science, Mahidol University, Rama VI Rd, Bangkok 10400, Thailand and ${ }^{2}$ Department of \\ Parasitology, Phramongkutklao College of Medicine, Ratchawithi Rd, Bangkok 10400, Thailand \\ Email: Rommanee Khositnithikul - kik_kuru@yahoo.com; Peerapan Tan-ariya -scptn@mahidol.ac.th; \\ Mathirut Mungthin* - mathirut@pmk.ac.th \\ * Corresponding author
}

Published: 28 January 2008

Malaria Journal 2008, 7:23 doi:10.1 186/1475-2875-7-23

This article is available from: http://www.malariajournal.com/content/7///23

(C) 2008 Khositnithikul et al; licensee BioMed Central Ltd.

This is an Open Access article distributed under the terms of the Creative Commons Attribution License (http://creativecommons.org/licenses/by/2.0), which permits unrestricted use, distribution, and reproduction in any medium, provided the original work is properly cited.
Received: 29 October 2007
Accepted: 28 January 2008

\begin{abstract}
Background: The emergence of Plasmodium falciparum resistant to most currently used antimalarial drugs is the major problem in malaria control along the Thai-Myanmar and ThaiCambodia borders. Although artemisinin-based combination therapy has been recommended for the treatment of multidrug-resistant falciparum malaria, these combinations are not available for some people, such as travelers from North America. A fixed-dose combination of atovaquone and proguanil (Malarone) has been proved to be effective for the treatment and prophylaxis of malaria which is already approved by countries in North America and Europe. Determination of the phenotypes and genotypes related to atovaquone/proguanil response in Thai isolates of $P$. falciparum will be useful for rationale drug use. The main purpose of this study was to explore the in vitro atovaquone/proguanil susceptibility of recently adapted Thai isolates of $P$. falciparum. Genotypic characterization of the cytb gene of these isolates was also determined since it has been reported that point mutations, particularly codon 268 in the cytochrome b gene (cytb) have been linked to atovaquone/proguanil treatment failure.
\end{abstract}

Methods: Eighty three $P$. falciparum isolates collected during 1998 to 2005 from four different multidrug resistance areas of Thailand were determined for the in vitro atovaquone/proguanil susceptibilities using radioisotopic assay. Mutations in the cytb gene were determined by PCR-RFLP and sequence analysis.

Results: The mean atovaquone and proguanil $\mathrm{IC}_{50}$ was $3.4 \mathrm{nM}$ and $36.5 \mu \mathrm{M}$, respectively. All 83 Thai isolates were atovaquone sensitive. None of the 83 isolates contained the mutations at codon 268 of the cytb gene. DNA sequencing of the cytb gene of 20 parasite isolates showed no other mutations.

Conclusion: In agreement with a recent efficacy study of atovaquone/proguanil, the present information indicates that atovaquone/proguanil can be one of the drugs of choice for the treatment and prophylaxis of multidrug-resistant falciparum malaria in Thailand. 


\section{Background}

Multidrug-resistant falciparum malaria is a major health problem along Thai-Myanmar and Thai-Cambodia borders. WHO has recommended artemisinin-based combination therapy as the first-line treatment for uncomplicated falciparum malaria in these multidrug resistance areas. In Thailand, a combination of artesunate and mefloquine has been used for more than 10 years. Recently, reduced efficacy of this combination has been reported from ThaiCambodia border [1]. Effective chemoprophylaxis for malaria in these multidrug resistance areas is also needed especially for non-immune travelers. Thus the alternative drugs or drug combinations should be considered. Malarone ${ }^{\circledast}$ is a fixed-dose combination of atovaquone and proguanil. It is highly effective for the treatment and prophylaxis of multidrug-resistant falciparum malaria $[2,3]$. Atovaquone exerts its action via inhibiting plasmodial mitochondria electron transport at the level of the cytochrome $\mathrm{bc}_{1}$ complex and collapsing mitochondrial membrane potential $[4,5]$. In addition, it inhibits dihydroorotate dehydrogenase (DHOD) enzyme which catalyses the reaction from dihydroorotate to orotate [6]. Therefore, atovaquone can inhibit both nucleic acid and ATP synthesis. Proguanil was added for the synergistic effect which is probably due to enhancing atovaquone to collapse mitochondrial membrane potential [7].

A few cases of atovaquone-proguanil (AP) treatment failure have been reported, mainly from Africa [8-16]. Treatment failure of $\mathrm{AP}$ in these patients was due to atovaquone resistance and has been linked to point mutations in the target gene of atovaquone, Plasmodium falciparum mitochondrial cytb gene, i.e. Tyr268Ser, Tyr268Asn and Tyr268Cys. Codon 268 of the cytb gene is a region encoding the putative atovaquone-binding domain [17]. Tyrosine $(\mathrm{Y})$ at position 268 is conserved bulky hydrophobic contact of the drug in the Qo II region of the ubiquinol oxidation site. Substitution of serine (S), a hydrophilic amino acid, limits hydrophobic contact with atovaquone. This reason explains the marked decrease in atovaquone susceptibility in mutated malaria parasites $[8,17]$. Substitution of the less bulky asparagine $(\mathrm{N})$ at position 268 not only reduced the volume of the binding pocket but it also decreases the affinity and binding of atovaquone [8]. Thus, these mutations are considered as the main markers for the surveillance of AP resistance. To date, AP has not been routinely used for the treatment and prophylaxis of falciparum malaria in Thailand. However, recent study showed a high efficacy of AP for the treatment of multidrug-resistant falciparum malaria on Thailand-Myanmar border [18]. This combination may be considered as the alternative drugs for the treatment and prophylaxis of malaria especially for western nonimmune travelers. However, surveillance of AP resistance at the phenotypic and genotypic levels is necessary before this combination is recommended. Since recent report showed that AP-resistant genotype of $P$. falciparum can be detected in the non-exposed area. Happi et al found Tyr268Asn mutation in $P$. falciparum from Nigeria where AP has not been used; his finding suggests that the mutations in the $c y t b$ gene might naturally occur [19]. This study aimed to determine the in vitro atovaquone and proguanil sensitivity of adapted Thai isolates of $P$. falciparum from four different endemic areas. Genotypic characterization of the cytb gene of these isolates was also performed.

\section{Methods \\ Malaria parasites}

Eighty three isolates of $P$. falciparum were collected from four endemic areas along Thai-Myanmar border (Tak, Kanchanaburi and Ranong) and Thai-Cambodia border (Chantaburi) during 1998 to 2005. These isolates were adapted and cryopreserved in liquid nitrogen before used. Parasites were cultivated continuously in vitro by a modification of Trager and Jensen method [20].

\section{In vitro drug sensitivity assay}

In vitro atovaquone and proguanil susceptibility of these Thai isolates of $P$. falciparum was determined using modified radioisotopic method of Desjardins et al [21]. Both atovaquone and proguanil were kindly provided by Stephen A Ward (Liverpool School of Tropical Medicine, UK). Atovaquone was dissolved in dimethylsulfoxide (DMSO), whereas proguanil was dissolved in 50\% ethanol. The $\mathrm{IC}_{50}$ was eventually evaluated using the GRAFIT ${ }^{\circledast}$ programme (Erithacus Software Ltd., UK). The $\mathrm{IC}_{50}$ value of each isolate was the mean of at least three independent experiments. Comparisons of the $\mathrm{IC}_{50}$ values of parasites collected in different years and from different areas were analyzed using One-way ANOVA. The level of significance was set at $p<0.05$.

\section{PCR-RFLP for detection of mutations in the cytb gene}

$P$. falciparum DNA was isolated using chelex-resin as described by Wooden et al [22]. PCR-RFLP was performed to determine the three known polymorphisms at codon 268 of the $c y t b$ gene using primers CYTB3/CYTB5, CYTB2/ CYTB6 and CYTB2/CYTB7 as previously described [9]. For RFLP analysis, the PCR products of each pair of primers were digested with NsiI, AlwNI and SspI, respectively (New England Biolabs, UK). NsiI cut the wild type and asparagine mutation. AlwNI cut the serine mutation while SspI cut wild type and serine mutation but not the asparagine mutation. The digested PCR products were subsequently analyzed by agarose gel electrophoresis.

\section{DNA sequencing of the cytb gene}

Since the point mutations in the $c y t b$ gene at the codons other than 268, i.e. 133 and 284 were previously reported 
to be involved with atovaquone sensitivity, DNA sequencing of the $c y t b$ gene was also performed. Twenty isolates were randomly selected from 83 isolates collecting from different years and endemic areas. These 20 isolates also represented parasites with the highest and lowest atovaquone $\mathrm{IC}_{50}$ values. The primers pair of CYTB1 and CYTB2 was used for PCR amplification. The PCR products were sequenced by Macrogen Inc, Korea.

\section{Results and Discussion}

\section{In vitro atovaquone and proguanil susceptibility}

The mean atovaquone $\mathrm{IC}_{50}$ values of $P$. falciparum isolates in this study was $3.4 \pm 1.6(0.83-6.81 \mathrm{nM})$. While, the mean proguanil $\mathrm{IC}_{50}$ values was $36.5 \pm 7.0(21.2-49.6)$. The atovaquone and proguanil $\mathrm{IC}_{50}$ values of $P$. falciparum isolates obtained in various years and from various endemic areas were shown in Figure 1 and 2, respectively. The mean \pm SD of atovaquone $\mathrm{IC}_{50}$ values in 1998,2000 , 2002,2003 and 2005 were $3.4 \pm 1.6,2.8 \pm 1.6,3.8 \pm 1.5$, $3.2 \pm 1.6$ and $2.0 \pm 0.8 \mathrm{nM}$, respectively. The mean $\pm \mathrm{SD}$ of proguanil $\mathrm{IC}_{50}$ values in 1998, 2000, 2002, 2003 and 2005 were $39.9 \pm 7.8,34.8 \pm 5.1,39.2 \pm 7.4,33.8 \pm 5.9$ and $29.8 \pm 7.9 \mu \mathrm{M}$, respectively. The mean $\pm \mathrm{SD}$ of atovaquone $\mathrm{IC}_{50}$ value from Tak, Kanchanaburi, Ranong and Chantaburi were $3.4 \pm 1.6,3.3 \pm 1.6,2.9 \pm 1.5$ and 2.6 $\pm 1.6 \mathrm{nM}$, respectively. The mean $\pm \mathrm{SD}$ of proguanil $\mathrm{IC}_{50}$ value from Tak, Kanchanaburi, Ranong and Chantaburi were $36.7 \pm 7.28,35.0 \pm 9.3,34.9 \pm 4.3$ and $31.7 \pm 4.7 \mu \mathrm{M}$, respectively. The cut-off point used for atovaquone sensitive and atovaquone resistance was the $\mathrm{IC}_{50}$ of $<30 \mathrm{nM}$ and $>1900 \mathrm{nM}$, respectively [15]. Based on these criteria, all 83 Thai isolates were sensitive to atovaquone. Although the mean atovaquone $\mathrm{IC}_{50}$ value of these Thai isolates was apparently higher than African isolates

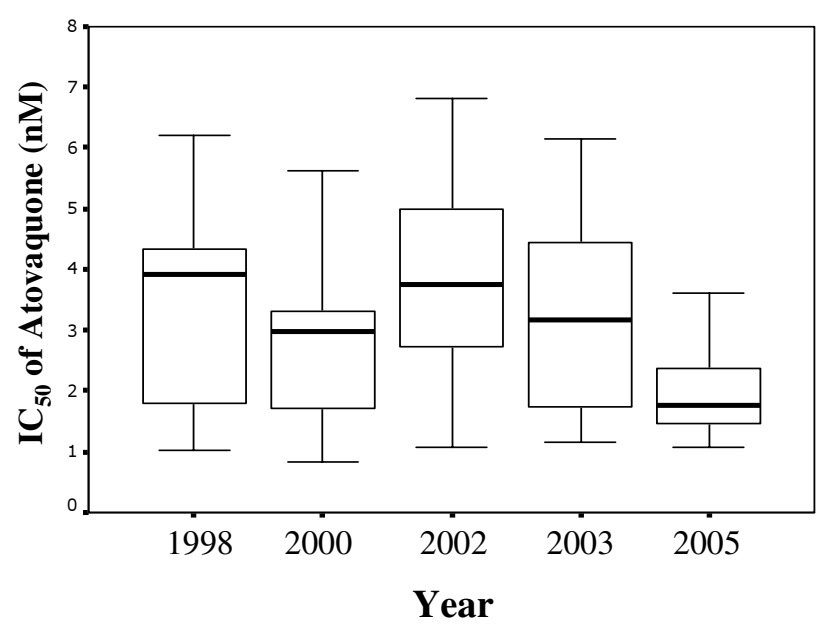

$[15,23]$, this $\mathrm{IC}_{50}$ value $(3.2 \mathrm{nM})$ was still classified in the range of atovaquone sensitive. Futhermore Gay et al determined the correlation of atovaquone and other antimalarial drugs in parasites isolated from the Philippines and found the significant correlations between of the $\mathrm{IC}_{50}$ of atovaquone and chloroquine, quinine, mefloquine, artemisinin and its derivatives [23]. The sensitivity of 83 isolates to other drugs was also determined and showed that there was no correlation among atovaquone and chloroquine, quinine, mefloquine and dihydroartemisinin $\mathrm{IC}_{50}$. The absence of the correlation of atovaquone and most available drugs in these isolates is a good evidence for the possibility of using $\mathrm{AP}$ as the alternative antimalarial drug in Thailand.

In this study, both atovaquone and proguanil sensitivity of these isolates were gradually decreased over the seven years of collection period. There were significantly differences between the proguanil $\mathrm{IC}_{50}$ values in the years 1998 and $2005(p=0.021)$ and in the year 2002 and $2005(p=$ $0.020)$. There was no difference of the atovaquone and proguanil $\mathrm{IC}_{50}$ values among the isolates adapted from different endemic areas.

\section{PCR-RFLP and sequencing}

Regarding to atovaquone, it has been reported that the mutations in the cytb gene especially at the codon 268 is responsible for atovaquone resistance [8-16]. In this study, all isolates were identified as wild-type genotype of the $c y t b$ gene at the codon 268. Sequence analysis also confirmed that all selected 20 isolates had a wild-type cytb gene at the codon 268. Recent studies showed a low prevalence of polymorphisms at the codon $268[13,24]$. These point mutations at the codon 268 seems to be sufficient, but not

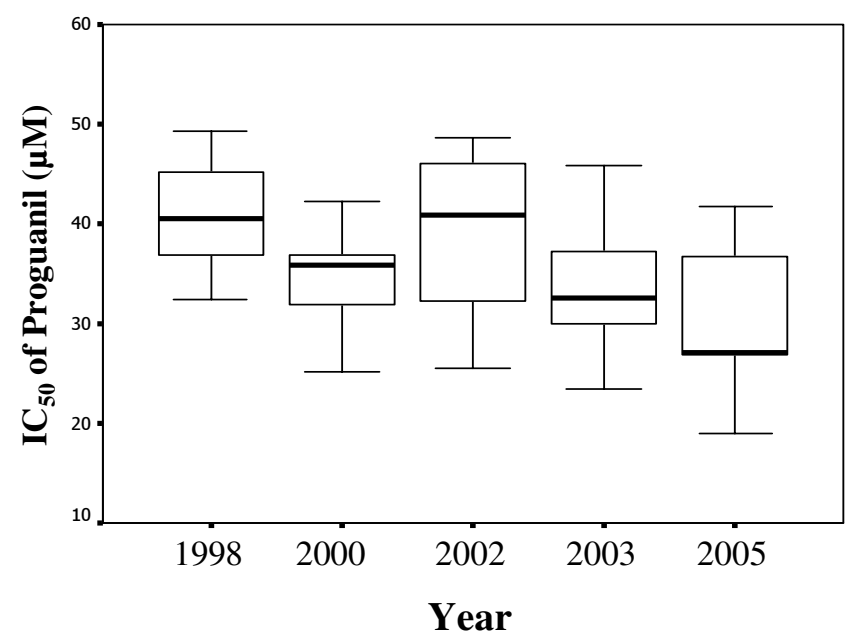

\section{Figure I}

Box plots of atovaquone and proguanil $I C_{50}$ of parasite isolates collected in different years. 

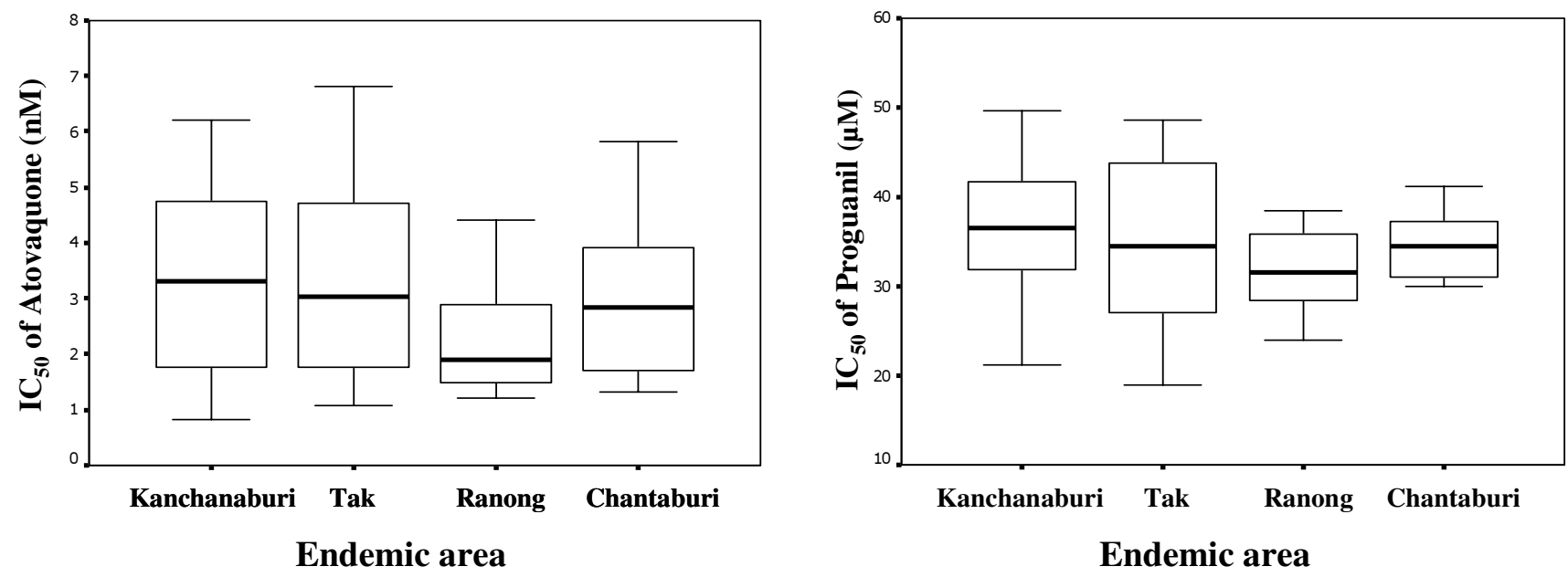

Figure 2

Box plots of atovaquone and proguanil IC $\mathrm{C}_{50}$ of parasite isolates collected from different endemic areas.

necessary, for AP treatment failure since the point mutations at this position were not identified in every treatment failure cases [13]. Other mutations i.e. M133I and V284K have been also linked to atovaquone resistance. From sequence analysis, there was no M133I and V284K mutation in all 20 isolates. The results of DNA sequencing were accorded well with the results of in vitro drug sensitivity assay and suggested that there was no atovaquone-resistant phenotype and genotype in these Thai isolates of $P$. falciparum. Similar results were previously reported in a study of parasite isolates from Thai-Myanmar border by NaoshimaIshibashi et al; all samples showed no mutations at the codon 268 of the cytb gene [25].

A recent efficacy study also showed that AP remained highly efficacious for the treatment of multidrug-resistant falciparum malaria in Thailand [18]. From both in vitro and in vivo information, AP can be considered as the drug of choice for the treatment and prophylaxis of falciparum malaria in Thailand.

\section{Conclusion}

The evidence from our study strongly supports the possibility of $\mathrm{AP}$ as an alternative antimalarial drug for the treatment and prophylaxis of multidrug-resistant falciparum malaria in Thailand.

\section{Authors' contributions}

PT and MM contributed to the conception and design of the study. RK performed in vitro susceptibility test and genotyping. RK, PT and MM analysed the data and wrote the manuscript. All authors read and approved the final version that was submitted for publication.

\section{Acknowledgements}

We would like to thank Prof. Stephen A Ward (Liverpool School of Tropical Medicine, UK) who kindly provided atovaquone and proguanil. This study was financially supported by the Phramongkutklao Research Fund.

\section{References}

I. Vijaykadga S, Rojanawatsirivej C, Cholpol S, Phoungmanee D, Nakave $A$, Wongsrichanalai $C$ : In vivo sensitivity monitoring of mefloquine monotherapy and artesunate-mefloquine combinations for the treatment of uncomplicated falciparum malaria in Thailand in 2003. Trop Med Int Health 2006, I I:21 I-219.

2. Osei-Akoto A, Orton L, Owusu-Ofori SP: Atovaquone-proguanil for treating uncomplicated malaria. Cochrane Database Syst Rev 2005, 4:CD004529.

3. Nakato $H$, Vivancos $R$, Hunter PR: A systematic review and meta-analysis of the effectiveness and safety of atovaquone proguanil (Malarone) for chemoprophylaxis against malaria. Antimicrob Chemother 2007, 60:929-936.

4. Srivastava IK, Rottenberg H, Vaidya AB: Atovaquone, a broad spectrum antiparasitic drug, collapses mitochondrial membrane potential in a malarial parasite. J Biol Chem 1997, 272:396I-3966

5. KessI J], Ha KH, Merritt AK, Lange BB, Hill P, Meunier B, Meshnick SR, Trumpower BL: Cytochrome b mutations that modify the ubiquinol-binding pocket of the cytochrome bcl complex and confer anti-malarial drug resistance in Saccharomyces cerevisiae. J Biol Chem 2005, 280: 17|42-17|48.

6. Ittarat I, Asawamahasakda W, Meshnick SR: The effects of antimalarials on the Plasmodium falciparum dihydroorotate dehydrogenase. Exp Parasitol 1994, 79:50-56.

7. Srivastava I, Vadiya A: A mechanism for the synergistic antimalarial action of atovaquone and proguanil. Antimicrob Agents Chemother 1999, 43:1334-1339.

8. Fivelman QL, Butcher GA, Adagu IS, Warhurst DC, Pasvol G: Malarone treatment failure and in vitro confirmation of resistance of Plasmodium falciparum isolate from Lagos, Nigeria. Malar J 2002, I:I.

9. Schwobel B, Alifrangis M, Salanti A, Jelinek T: Different mutation patterns of atovaquone resistance to Plasmodium falciparum in vitro and in vivo: rapid detection of codon 268 polymorphisms in the cytochrome $b$ as potential in vivo resistance marker. Malar J 2003, 2:5.

10. David KP, Alifrangis M, Salanti A, Vestergaard LS, Ronn A, Bygbjerg IB: Atovaquone/proguanil resistance in Africa: a case report. Scand J Infect Dis 2003, 35:897-898. 
11. Farnert A, Lindberg J, Gil P, Swedberg G, Berqvist Y, Thapar MM, Lindegardh N, Berezcky S, Bjorkman A: Evidence of Plasmodium falciparum malaria resistant to atovaquone and proguanil hydrochloride: case reports. BMJ 2003, 326:628-629.

12. Schwartz E, Bujanover S, Kain KC: Genetic confirmation of atovaquone-proguanil-resistant Plasmodium falciparum malaria acquired by a nonimmune traveler to East Africa. Clin Infect Dis 2003, 37:450-45I.

13. Wichmann O, Muehlberger N, Jelinek T, Alifrangis $M$, Peyerl-Hoffmann G, Muhlen M, Grobusch MP, Gascon J, Matteelli A, Laferl H, Bisoffi Z, Ehrhardt S, Cuadros J, Hatz C, Gjorup I, McWhinney P, Beran J, da Cunha S, Schulze M, Kollaritsch H, Kern P, Fry G, Richter J, European Network on Surveillance of Imported Infectious Diseases: Screening for mutations related to atovaquone/proguanil resistance in treatment failures and other imported isolates of Plasmodium falciparum in Europe. J Infect Dis 2004, 190:154I-1546.

14. Kuhn S, Gill M], Kain KC: Emergence of atovaquone-proguanil resistance during treatment of Plasmodium falciparum malaria acquired by a non-immune north American traveller to west Africa. Am J Trop Med Hyg 2005, 72:407-409.

15. Musset L, Pradines B, Parzy D, Durand R, Bigot P, Le Bras J: Apparent absence of atovaquone/proguanil resistance in 477 Plasmodium falciparum isolates from untreated French travellers. J Antimicrob Chemother 2006, 57: I I0-II5.

16. Musset L, Bouchaud O, Matheron S, Massias L, Le Bras J: Clinical atovaquone-proguanil resistance of Plasmodium falciparum associated with cytochrome b codon $\mathbf{2 6 8}$ mutations. Microbes Infect 2006, 8:2599-2604.

17. Korsinczky M, Chen N, Kotecka B, Saul A, Rieckmann K, Cheng Q: Mutations in Plasmodium falciparum cytochrome $b$ that are associated with atovaquone resistance are located at a putative drug-binding site. Antimicrob Agents Chemother 2000, 44:2100-2108.

18. Krudsood S, Patel SN, Tangpukdee N, Thanachartwet W, Leowattana W, Pornpininworakij K, Boggild AK, Looareesuwan S, Kain KC: Efficacy of atovaquone-proguanil for treatment of acute multidrug-resistant Plasmodium falciparum malaria in Thailand. Am J Trop Med Hyg 2007, 76:655-658.

19. Happi CT, Gbotosho GO, Folarin OA, Milner D, Sarr O, Sowunmi A, Kyle DE, Milhous WK, Wirth DF, Oduola AM: Confirmation of emergence of mutations associated with atovaquone-proguanil resistance in unexposed Plasmodium falciparum isolates from Africa. Malar J 2006, 5:82.

20. Trager W, Jensen JB: Human malaria parasites in continuous culture. Science 1976, 193:673-675.

21. Desjardins RE, Canfield CJ, Haynes JD, Chulay JD: Quantitative assessment of antimalarial activity in vitro by a semiautomated microdilution technique. Antimicrob Agents Chemother 1979, 16:710-718.

22. Wooden J, Gould EE, Paull AT, Sibley CH: Plasmodium falciparum: a simple polymerase chain reaction method for differentiating strains. Exp Parasitol 1992, 75:207-212.

23. Gay F, Bustos D, Traore B, Jardinel C, Southammavong M, Ciceron L, Danis MM: In vitro response of Plasmodium falciparum to atovaquone and correlation with other antimalarials: comparison between African and Asian strains. Am J Trop Med Hyg 1997, 56:315-317.

24. Berry A, Senescau A, Lelièvre J, Benoit-Vical F, Fabre R, Marchou B, Magnaval JF: Prevalence of Plasmodium falciparum cytochrome b gene mutations in isolates imported from Africa, and implications for atovaquone resistance. Trans $R$ Soc Trop Med Hyg 2006, 100:986-988.

25. Naoshima-Ishibashi $Y$, Iwagami M, Kawazu S, Looareesuwan S, Kano S: Analyses of cytochrome b mutations in Plasmodium falciparum isolates in Thai-Myanmar border. Travel Med Infect Dis 2007, 5: 132-134.
Publish with Bio Med Central and every scientist can read your work free of charge

"BioMed Central will be the most significant development for disseminating the results of biomedical research in our lifetime. "

Sir Paul Nurse, Cancer Research UK

Your research papers will be:

- available free of charge to the entire biomedical community

- peer reviewed and published immediately upon acceptance

- cited in PubMed and archived on PubMed Central

- yours - you keep the copyright
BioMedcentral 